\title{
ACADEMIC AND EDUCATIONAL PRODUCTION OF A MASTER'S STUDENT IN EPT OF IFAP MACAPÁ, AMAPÁ, AMAZÔNIA, BRAZIL
}

\section{ORIGINAL ARTICLE}

VIANA, Valderi Nascimento ${ }^{1}$, FECURY, Amanda Alves², OLIVEIRA, Euzébio de ${ }^{3}$, DENDASCK, Carla Viana ${ }^{4}$, DIAS, Claudio Alberto Gellis de Mattos ${ }^{5}$

VIANA, Valderi Nascimento. Et al. Academic and educational production of a master's student in EPT of IFAP Macapá, Amapá, Amazônia, Brazil. Revista Científica Multidisciplinar Núcleo do Conhecimento. Year 06, Ed. 06, Vol. 08, pp. 186200. June 2021. ISSN: 2448-0959, Access link: https://www.nucleodoconhecimento.com.br/education/masters-student, DOI: 10.32749/nucleodoconhecimento.com.br/education/masters-student

\section{SUMMARY}

Scientific production within undergraduate and graduate courses has its importance for the construction of a new way of thinking of the student. The Professional Master's Degree in Professional Education in National Network (ProfEPT) unites disciplinary content, pedagogical knowledge, and the final academic production and links them to real situations of educational practice, and the final work can be presented in various ways (articles, books, educational products). The academic production, both of the advisor and the guiding, in addition to the importance related to scientific dissemination, has weight in the evaluation of the program and also in its maintenance.

\footnotetext{
${ }^{1}$ Physical Educator, Specialist in Exercise Physiology and Sports Nutrition (FAMA), Student of the Graduate Program in Professional and Technological Education (PROFEPT IFAP).

${ }^{2}$ Biomedical, PhD in Tropical Diseases, Professor and researcher of the Medical Course of Macapá Campus, Federal University of Amapá (UNIFAP).

${ }^{3}$ Biologist, PhD in Tropical Diseases, Professor and researcher of the Physical Education Course of the Federal University of Pará (UFPA).

${ }^{4}$ Theologian, PhD in Clinical Psychoanalysis. He has been working for 15 years with Scientific Methodology (Research Method) in the Scientific Production Guidance of master's and Doctoral students. Specialist in Market Research and Research focused on health. PhD student in Communication and Semiotics (PUC SP). ${ }^{5}$ Biologist, PhD in Theory and Behavior Research, Professor and researcher of the Chemistry Degree Course of the Institute of Basic, Technical and Technological Education of Amapá (IFAP) and the Graduate Program in Professional and Technological Education (PROFEPT IFAP).
} 
The objective of this work is to quantitatively show the academic and educational production of a master's student in Professional and Technological Education (EPT) from the Institute of Education, Science and Technology (IFAP) of Macapá, Amapá, Amazônia, Brazil. During the master's degree, scientific production in various forms proved necessary during the training process. Uniting the theory with the practice of writing, facilitated the production of the dissertation that should be presented at the end of the course. Through the organization process, planning of ideas resulted in a new thought structured according to the standards of the academy, but that is not limited to this space and norms. The production during the master's degree seeks to contribute both quantitatively and qualitatively to the scientific production of the northern region, positively impacting it and the master's program. In addition to the importance in the contribution of scientific creation and dissemination, the productions tend to positively impact the evaluation and maintenance of the PROFEPT-IFAP program, carried out by CAPES.

Keywords: EPT, Dissemination, Scientific Production, PRORFEPT.

\section{INTRODUCTION}

Uniting theoretical and methodological instruments opportunities the realization of new projects, the student ceases to be just a repeater and begins to produce knowledge, contributing with a specific theme or area. Through the construction of one's own thought, they produce new attitudes and behaviors, that is, it exposes a plausible and structured idea, presenting value judgments and critical sense with a valid and logical argumentation (Maia, 2008).

The Professional Master's Degree in Professional Education in National Network (ProfEPT) emerges as an opportunity for specific training on Professional and Technological Education for both employees of the Federal Institutes and the external population, having the production of knowledge through educational products and research achievements that relate to the world of work. In this modality, the objective is the union of disciplinary content and pedagogical knowledge, the final academic production must be linked to real situations of educational practice, and the final work 
can be presented in various ways (Machado and Urbanetz, 2019; Urbanetz et al., 2020).

For the production and publication of scientific knowledge, guidance plays a fundamental role. The advisor having extensive experience in publishing, becomes a mentor for his mentoring, positively impacting productivity, being responsible for learning progress and success in the student's future. That is, all the experience gained during the training process has a positive impact on the academic life of the student, the skills and skills for publication are learned during the training (Falaster et al., 2017).

According to the evaluation form for academic and professional programs (Area 46: Teaching) of the Coordination for the Improvement of Higher Education Personnel (CAPES):

[...] the relevant minimum production capacity of pd will be evaluated, and may involve students and graduates. Also, the adherence and alignment of the production indicated by the PPG DP (four productions) with its concentration area and research lines will be evaluated, reflecting the coherence of the production with the objectives and identity of the Program. [...] For this, the PPG will indicate up to five bibliographic productions and up to five PTT published in the four-year period involving students and graduates. [...] the relevance of the indicated production in relation to the impact and innovative character of intellectual production, local, regional, national or international coverage, and meeting social demands. (Capes, 2020).

The academic production, both of the advisor and the mentor, in addition to the importance related to scientific dissemination, has weight in the evaluation of the stricto sensu graduate program and also in its maintenance.

\section{GOAL}

Quantitatively demonstrate the academic and educational production of a master's student in Professional and Technological Education (EPT) from the Institute of Education, Science and Technology (IFAP) of Macapá, Amapá, Amazônia, Brazil. 


\section{METHODOLOGY}

This article exposes the intellectual production developed during ProfEPT - IFAP. These productions that can be classified as bibliographic production (article in periodical, book) and technical production (application - APP, website)

Quantitative surveys to obtain data about the application and website used the period from April 12, 2021 to June 14, 2021. Data about the app was taken from the Play Console (Playconsole, 2021) and the Google Analytics website (Googleanalytics, 2021).

For the books and scientific articles, the original publication date was used until June 14, 2021. Data on them were taken from the online data (books and articles in the Revista Multidisciplinar Núcleo do Conhecimento) (Rmnc, 2021) and also by direct consultation of the journal (article published in Research, Society and Development journal) (Rsd, 2021).

\section{RESULTS}

\section{EFE APPLICATION (EDUFISEPT)}

Figure 1 shows the percentage of EFE application installations by the source of information traffic between April 12 and June 14, 2021. Data shows that 21.67\% (13 users) arrived at the app through search within the Google play store and 78.30\% (47 users) via third-party link. 
Figure 1 - Shows the percentage of EFE application installations by the source of information traffic between April 12 and June 14, 2021.

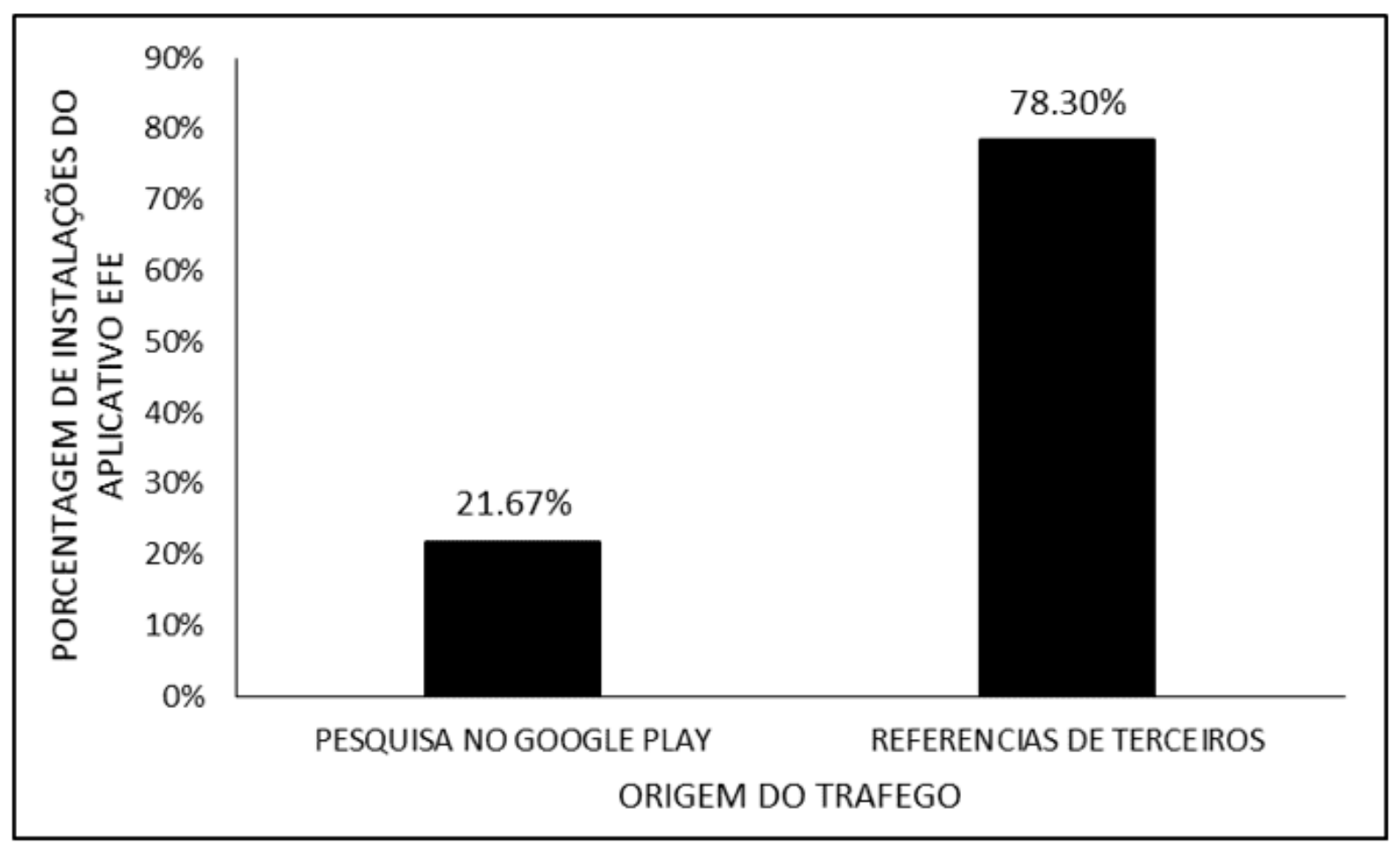

Source: Adapted from Playconsole (2021)

Regarding the analysis of the percentage of installations of the EFE application by the user's country, between April 12 and June 14, 2021, there was a record of downloads in two countries, being $98.33 \%$ (59 downloads) from Brazil and 1.67\% from Portugal (01 download) (Figure 2). 
Figure 2 - Shows the percentage of EFE app installations by user country between April 12 and June 14, 2021.

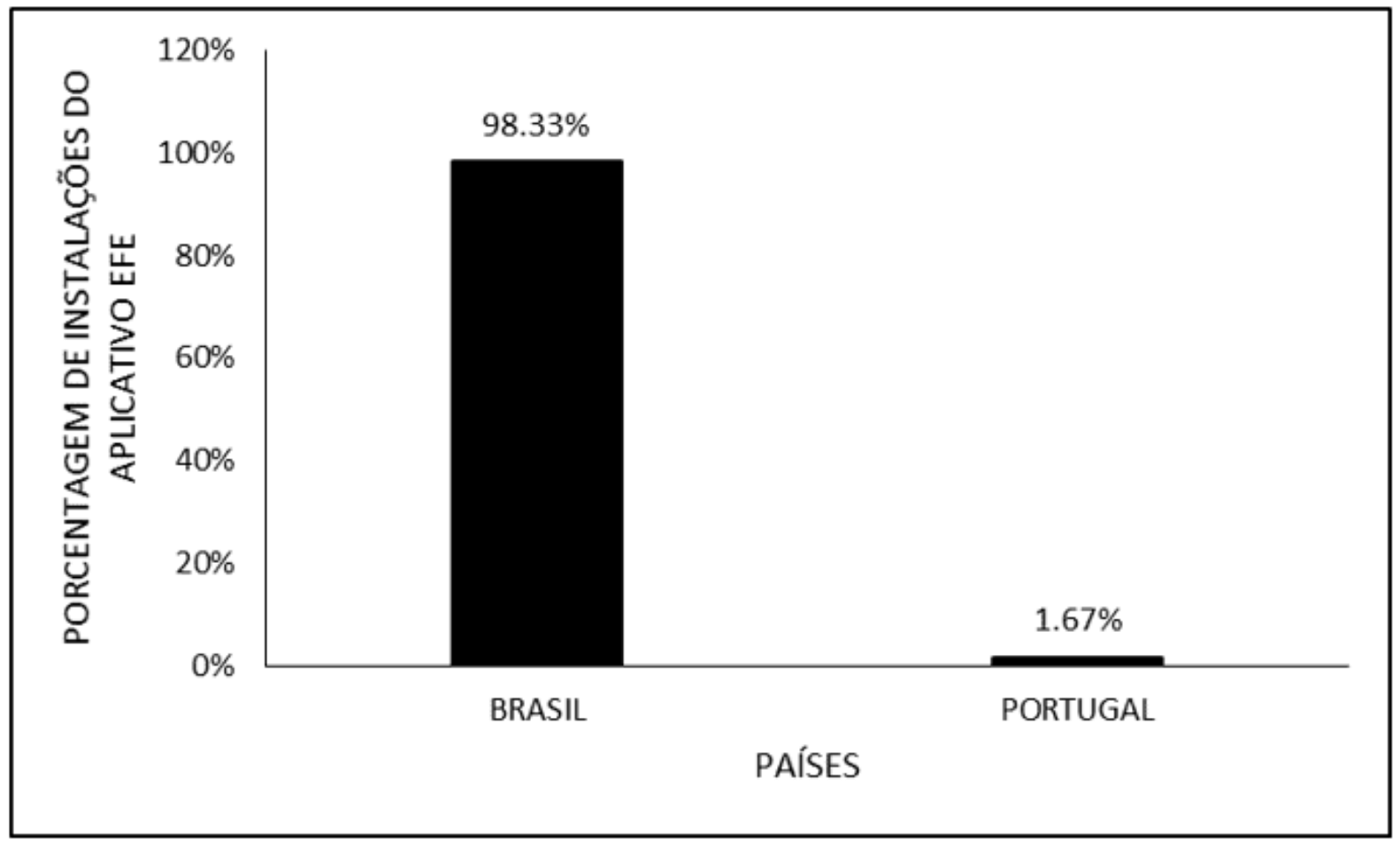

Source: Adapted from Playconsole (2021)

The percentage of EFE app installs by app visit and installation between April 12 and June 14, 2021 can be seen in Figure 3. Of 100\% of in-store page visitors (82 people), $73.17 \%(60)$ people) downloaded the application to their mobile device (Figure 3). 
Figure 3 - Shows the percentage of EFE app installs by app visit and install, between April 12th and June 14th, 2021.

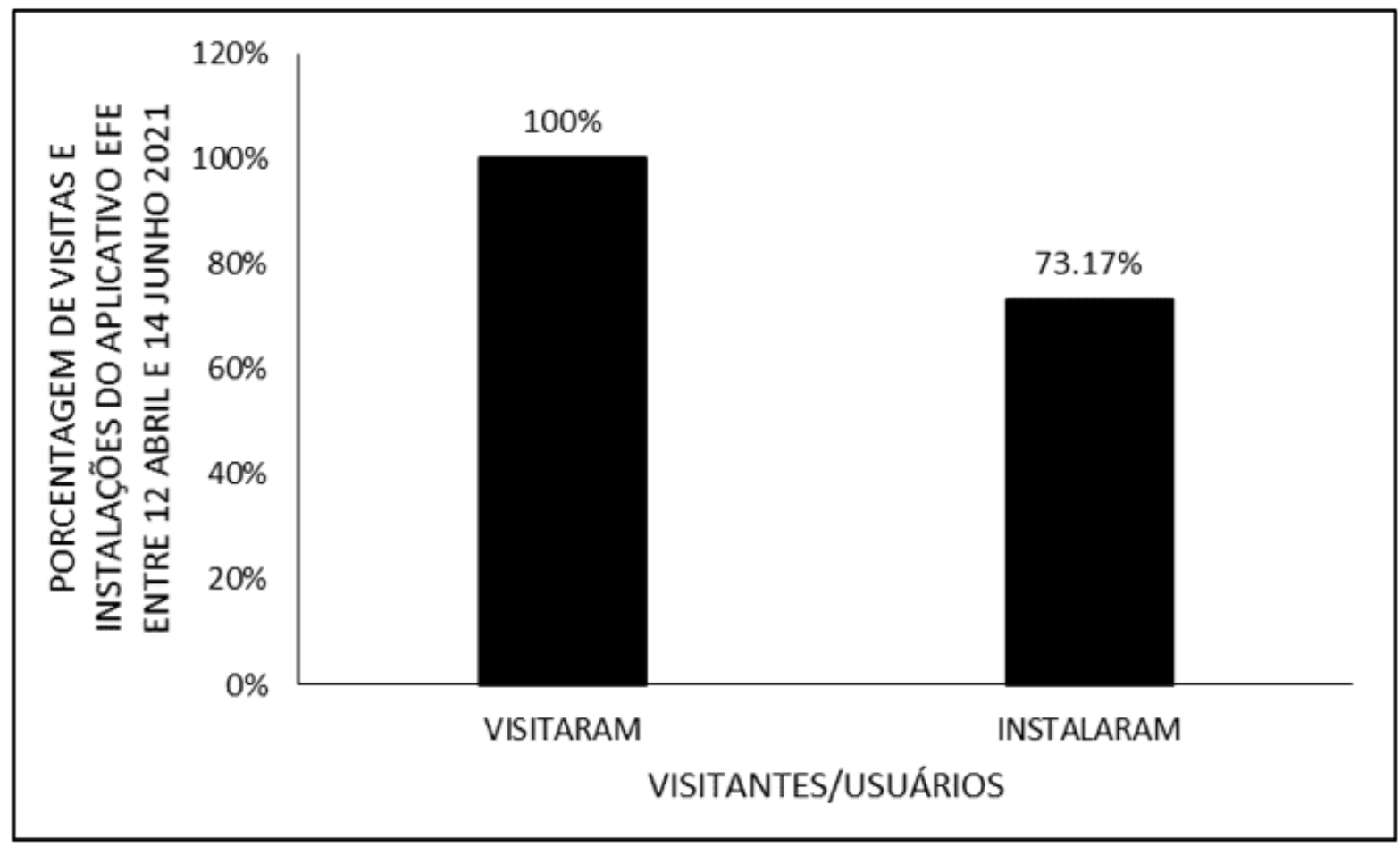

Source: Adapted from Playconsole (2021).

Figure 4 shows the percentage of EFE app installations by user types between April 12 and June 14, 2021. Of the total (60 users), 93.33\% (56 people) are new users and $6.67 \%$ (04 people) are recurring users within the application, that is, accessed the APP several times. 
Figure 4 - Shows the percentage of EFE app installations by user types between April 12 and June 14, 2021.

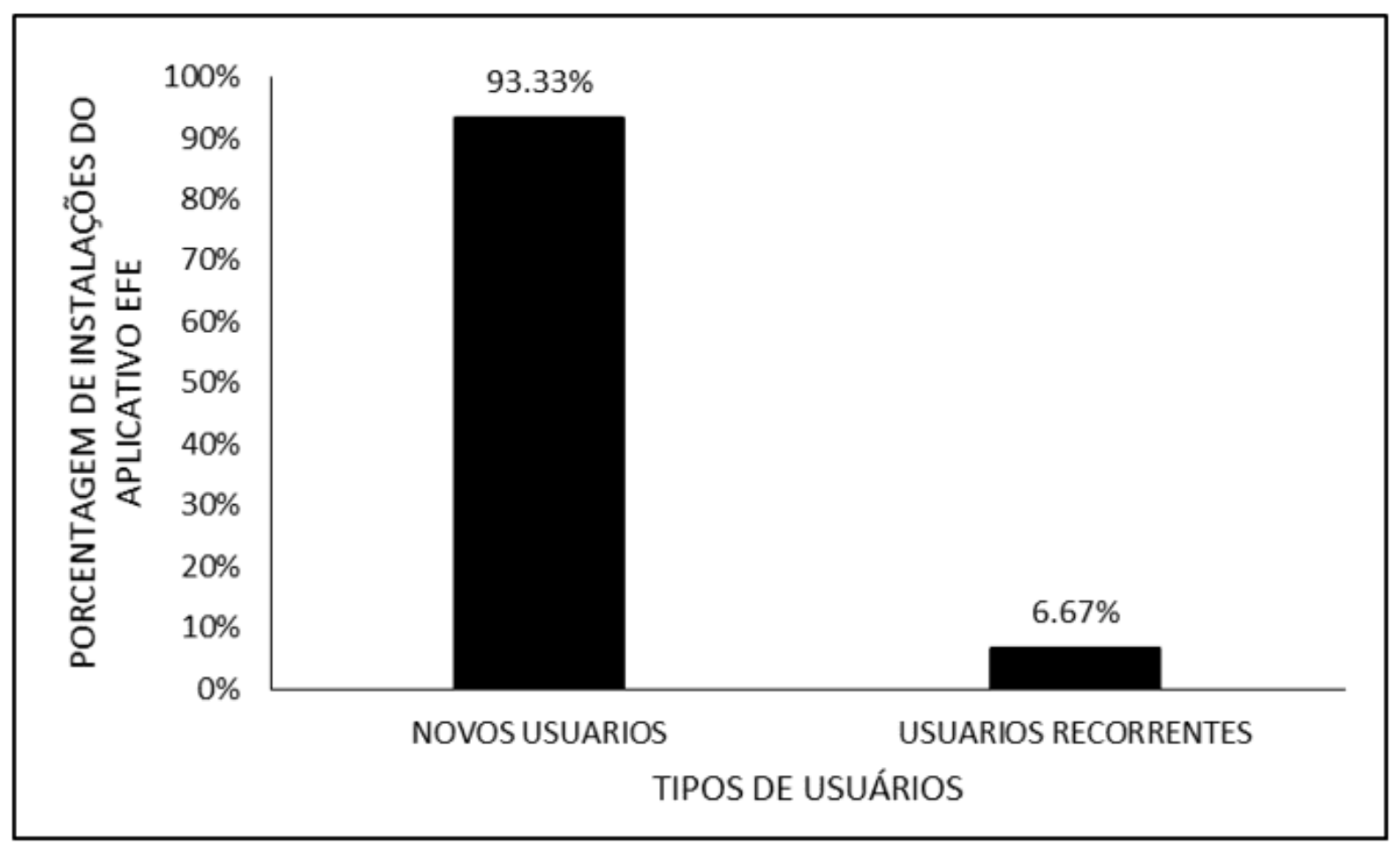

Source: Adapted from Playconsole (2021).

\section{SITE}

Regarding the percentage of accesses to the EduFisEPT site by internal pages of the site, between April 12 and June 14, 2021, the page with the most access among the 1399 users (100\%) is pedagogical practices with $30.38 \%$ (425 people). Next the Page of Sports with $17.23 \%$ (241 people accessing), Authors with 13.37\% (187 people), Collaborate with $13.22 \%$ (185 people), Games and games with $7.79 \%$ (109 people accessing), Dances 5.65\% (79 people), Health with 5.00\% (70 people), Leisure with $4.43 \%$ (62 people) and Fights with 2.91\% (41 people) (Figure 5). 
Figure 5 - Shows the percentage of EduFisEPT site accesses per internal page between April 12 and June 14, 2021.

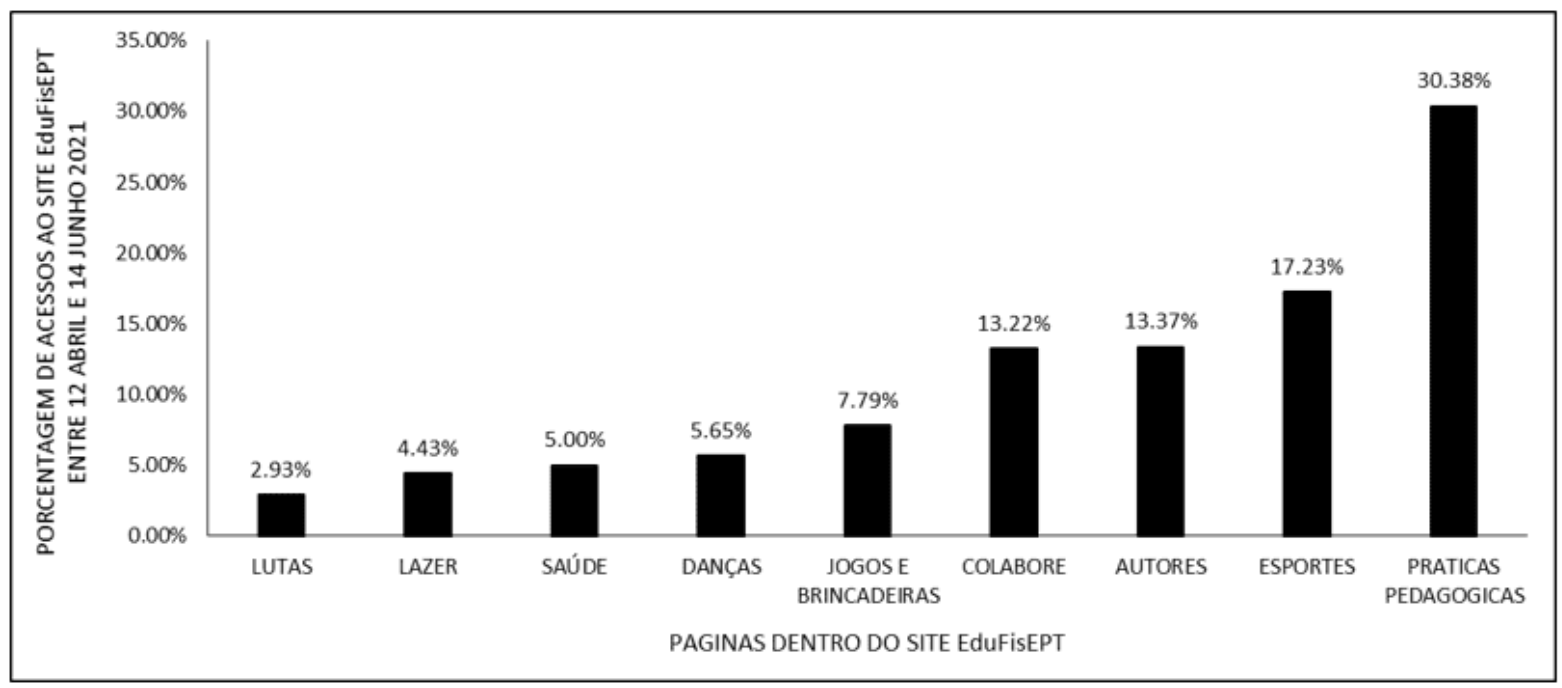

Source: Adapted from GoogleAnalytics (2021).

The percentage of eduFisEPT site accesses by countries, between April 12 and June 14, 2021, brings Brazil with 93.92\% (1314 people) accesses, followed by Portugal with 2.64\% (37 people), United States with 1.50\% (21 people), Mozambique 1.07\% (15 people), $1.07 \%$, and Ireland with $0.86 \%$ (12 people) (Figure 6 ). 
Figure 6 - Shows the percentage of accesses to the EduFisEPT website by countries between April 12 and June 14, 2021.

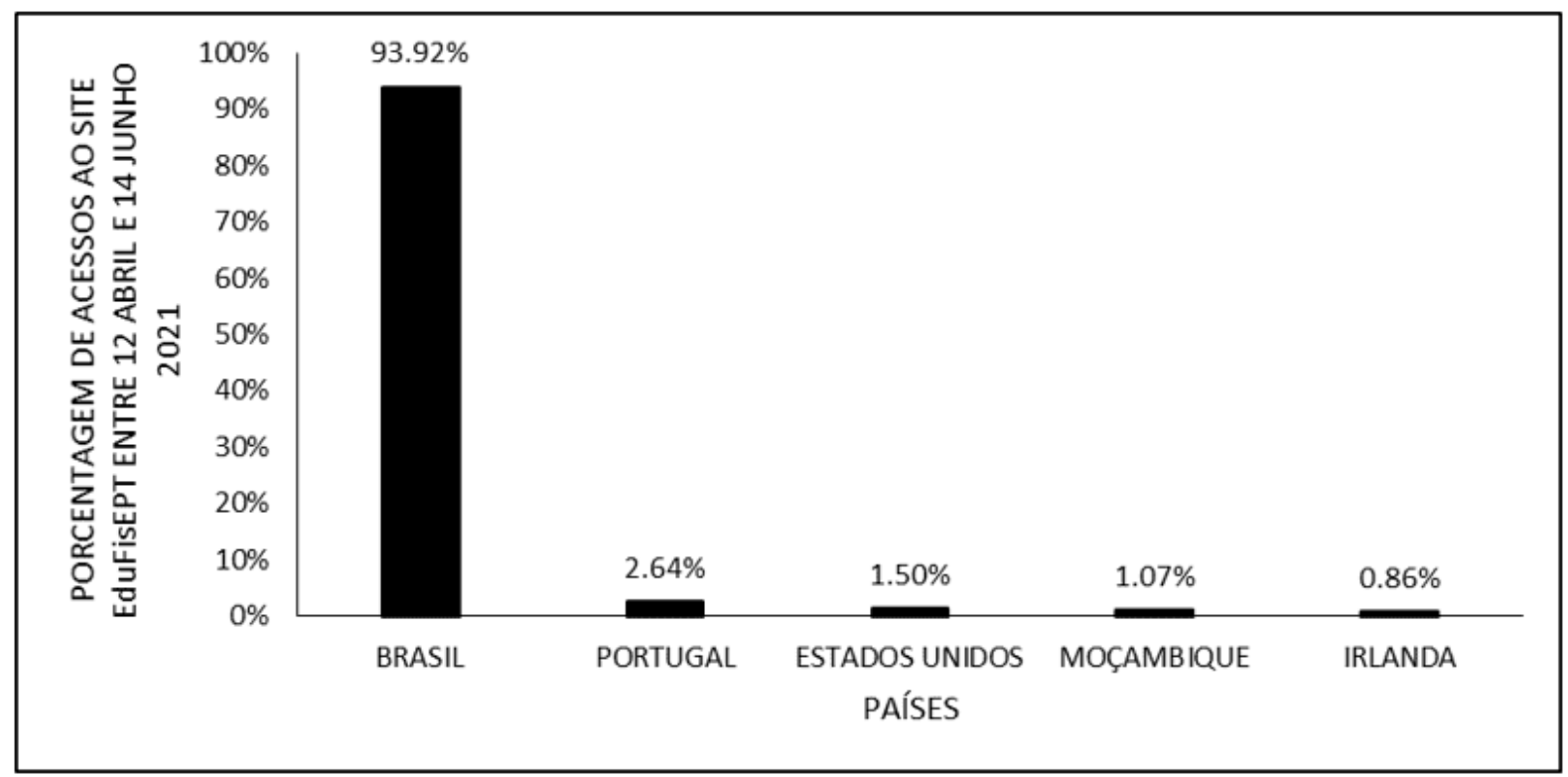

Source: Adapted from GoogleAnalytics (2021).

\section{BOOKS}

Figure 7 shows the cover of the book published in Portuguese (BR) on September 30, 2020. Since its publication, the book has accumulated a total of 715 views. 
Figure 7 - Shows the cover of the book published in Portuguese (BR) on September 30, 2020.

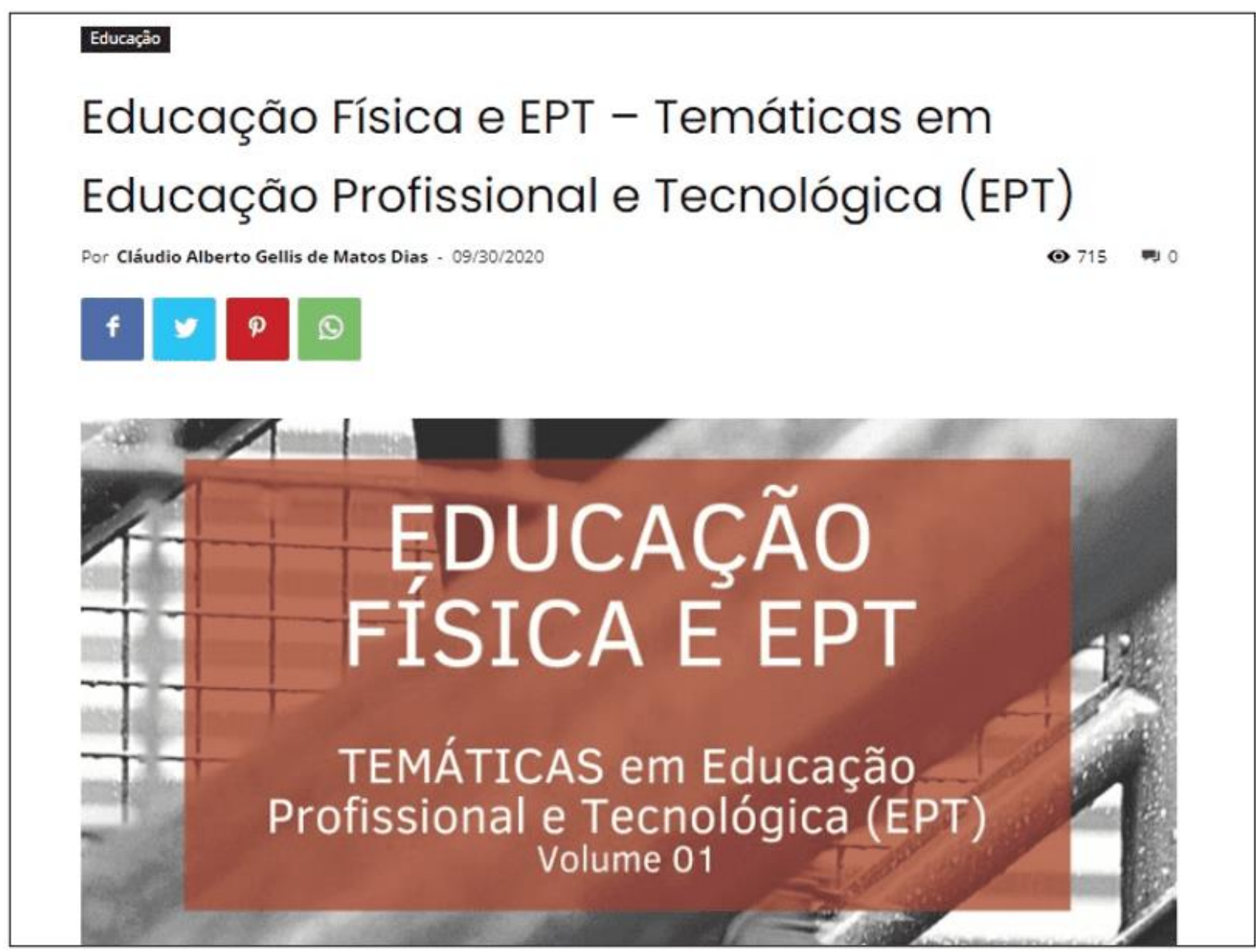

Source: Adapted from Viana and Dias (2020).

The book published in English (version of the book in Portuguese) on December 10, 2020 accumulates 248 views since then (Figure 8 ). 
Figure 8 - Shows the cover of the book published in English on December 10, 2020.

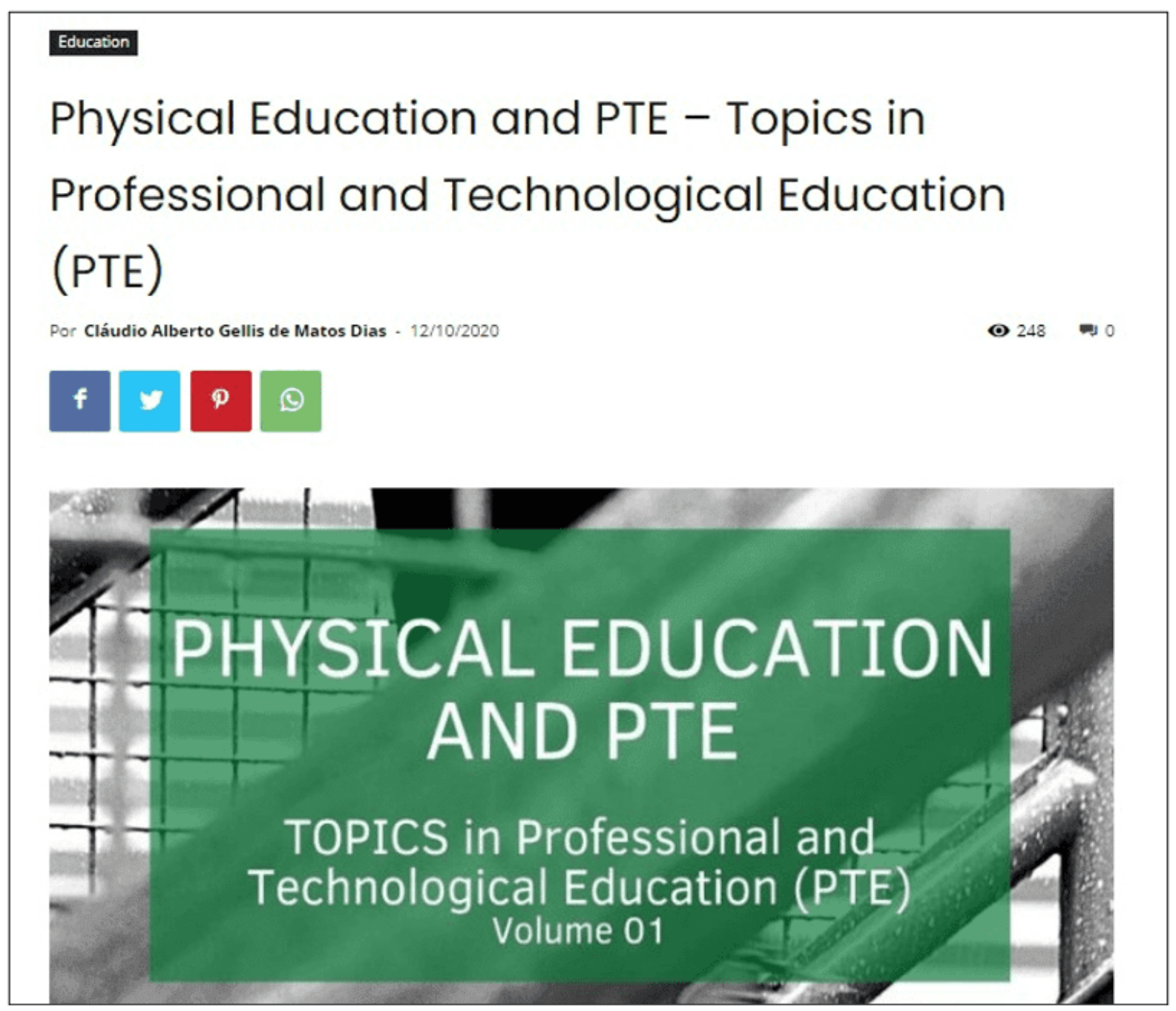

Source: Adapted from Viana and Dias (2020b).

\section{ARTICLES PUBLISHED IN INDEXED JOURNALS}

The article published in the journal Research, Society and Development (Qualis 20132016 B2 and Qualis reference A3) on July 2, 2020 had, according to the editors information, 91 views (Figure 9). 
Figure 9 - Shows the cover of the article published in the journal Research, Society and Development on July 2, 2020.

\begin{tabular}{|} 
Research, Society and Development, v. 9, n. 8, e239985704, 2020 \\
(CC BY 4.0) | ISSN 2525-3409 | DOI: http://dx.doi.org/10.33448/rsd-v9i8.5704 \\
Quadras de esportes em condições de uso adequado no Brasil: \\
influência no ensino-aprendizagem nas aulas de Educação Física (2015) \\
Sports courts in conditions of proper use in Brazil: influence on teaching-learning in \\
Physical Education classes (2015) \\
Canchas deportivas en condiciones de uso adecuado en Brasil: \\
influencia en la enseñanza-aprendizaje en las clases de Educación Física (2015) \\
Recebido: 16/06/2020 | Revisado: 18/06/2020 | Aceito: 22/06/2020 | Publicado: 02/07/2020 \\
ORCD: https:/orcid.org/0000-0002-0885-5834 \\
Instituto Federal do Amapá, Brasil \\
E-mail: wallderinascimento@gmail.com
\end{tabular}

Figure 10 shows the cover of the manual on the EFE application published in the Revista Multidisciplinar Núcleo do Conhecimento (Qualis reference B3) on April 14, 2021. The publication in Portuguese had 244 views. 
Figure 10 - Shows the cover of the manual on the EFE application published in the Multidisciplinary Journal Núcleo do Conhecimento on April 14, 2021.

\section{Educaçâo Física}

MANUAL DE PRATICAS EM EDUCAÇÃO FÍSICA NA EDUCAÇÃO PROFISSIONAL E TECNOLÓGICA UTILIZANDO O APLICATIVO GRATUITO EFE - EPTFIS

Por Carla Dendasck - RC: $82194 \cdot 14 / 04 / 2021$

DOI: $10.32749 /$ nucleodoconhecimento.com.br/educacao-fisica/manual-de-praticas

\section{ARTIGO ORIGINAL}

VIANA, Valderi Nascimento [1], FECURY, Amanda Alves [2], OLIVEIRA, Euzébio de [3], DENDASCK, Carla Viana ${ }^{[4]}$, DIAS, Claudio Alberto Gellis de Mattos ${ }^{[5]}$

Source: Adapted from Viana et al. (2021).

The manual was published in six more languages, in addition to the Portuguese language. Table 1 shows the number of accesses (and the URL) to the manual on the EFE application published in the Revista Multidisciplinar Núcleo do Conhecimento until June 14, 2021, by language. In total, from publication to june 14, 2021 there have been 374 views. 
Table 1 - Shows the number of accesses (and url) to the manual on the EFE application published in the Revista Multidisciplinar Núcleo do Conhecimento until June 14, 2021, by language.

\begin{tabular}{|c|c|c|}
\hline IDIOMA & $\begin{array}{c}\text { NÚMERO } \\
\text { DE } \\
\text { ACESSOS }\end{array}$ & LINK DE ACESSO \\
\hline PORTUGUES & 244 & $\begin{array}{l}\text { https://www.nucleodoconhecimento.com.br/e } \\
\text { ducacao-fisica/manual-de-praticas }\end{array}$ \\
\hline INGLES & 20 & $\begin{array}{l}\text { https://www.nucleodoconhecimento.com.br/e } \\
\text { ducation-physics-en/manual-of-practices }\end{array}$ \\
\hline ESPANHOL & 24 & $\begin{array}{l}\text { https://www.nucleodoconhecimento.com.br/e } \\
\text { ducacion-fisica-es/manual-de-practicas }\end{array}$ \\
\hline FRANCÊS & 23 & $\begin{array}{l}\text { https://www.nucleodoconhecimento.com.br/e } \\
\text { ducation-physics-fr/manuel-de-pratiques }\end{array}$ \\
\hline ITALIANO & 26 & $\begin{array}{l}\text { https://www.nucleodoconhecimento.com.br/e } \\
\text { ducazione-fisica-it/manuale-di-pratiche }\end{array}$ \\
\hline ALEMÃO & 21 & $\begin{array}{l}\text { https://www.nucleodocon hecimento.com.br/b } \\
\text { ildung-physik-de/handbuch-der-praktiken }\end{array}$ \\
\hline RUSSO & 16 & $\begin{array}{l}\text { https://www.nucleodoconhecimento.com.br/o } \\
\text { бразование-физика-ru/пособие-по-практике, }\end{array}$ \\
\hline TOTAL & 374 & \\
\hline
\end{tabular}

Source: Adapted from Viana et al. (2021), Viana et al. (2021b), Viana et al. (2021c), Viana et al. (2021d), Viana et al. (2021e), Viana et al. (2021f), Viana et al. (2021g).

\section{DISCUSSION}

Within the scientific environment, all theory and methodology seeks to bring the student closer to the knowledge produced by science. Within the training process, contact with the writing of articles, construction of websites and the application, the construction of research, data analysis and dissemination, proved to be of great importance. In each production there is a reality being researched, and this establishes a connection with sociocultural situations and contexts. The contextualization of knowledge is a tool for meaningful learning. It is opportunistic, new experience or 
knowledge resignification, is to develop the ability to analyze, hypotheses, critical sense within a current structure, since interaction with facts and phenomena of everyday life occurs (Yamaguchi and Furtado, 2019).

All materials published, physically or on-line, serveas a means of scientific dissemination. In the case of the application all the content covered are based on scientific knowledge, by easy and simple access. The teacher acquires new knowledge and can put into practice within the school in real time. According to Rossi (2019)

It remains to bring the science of articles and congresses closer to the lives of Brazilians who so much need almost everything with regard to health, quality of life, sustainability, mobility, uses of technology and citizenship.

Thus, both in the theoretical level (articles, books, website) and application of the app serve as a stimulus to scientific experience, is to think of science articulated with reality, access and language accessible to anyone who seeks knowledge. Dissemination is beyond taking a systematized knowledge, also serves to delight, motivate and stimulate the other. (Rossi, 2019).

In physical education, the vision of a practice refined in technique by technique or sports performance is still very strong. Performance and technique should be considered by the teacher, but not seen as priorities and should be within a standard of excellence without respecting the individuality of the student. Within a perspective of global formation, physical education classes must work their object of study in a wide dimension, since students are inserted within a society that has a culture and that produces meanings, as well as reveals contradictions of behaviors, attitudes that must be addressed/considered (Coutinho, 2010; Viana et al., 2020).

Thus, with scientific productions based on the human and social sciences only contribute to the area of physical education, surpassing only the use of health sciences, there is the possibility of placing physical education at the same level of relevance and importance of other components of the school curriculum (Balbino e Urt, 2018). During the search process, articles and books were translated into other languages. This 
attitude is important to expand the scope of research, and production can be related to both national and international literature, showing a capacity for communication, access, cooperation and support with what is being produced by the world within physical education (Coutinho, 2010).

Regarding scientific production in the North, Pereira e Silveira (2019) performed an analysis of the scientific production of researchers from the Northern Region at the National Meeting of Research in Science Education and reported that the North has the least amount of research present at the event. The study also shows that Amapá did not perform any presentation and work in the 2009, 2011, 2013, 2015 and 2017 editions. According to the study, the largest or smallest number of productions is related to the locality of the university campus, since they are responsible for most scientific activities. Corroborating the aforementioned study, Sidone et al. (2016) when doing an analysis of article production between the years 2007-2009 of the South and Southeast regions indicates that these were responsible for more than three quarters of total production. Other regions such as Northeast $15 \%$ and Midwest and North together did not reach $10 \%$ of the national total. In addition to the concentration of universities in the South and Southeast regions, another factor pointed to this production is the greater availability of human resources.

\section{CONCLUSIONS}

During the master's degree, scientific production in various forms proved necessary during the training process. Uniting the theory with the practice of writing, facilitated the production of the dissertation that should be presented at the end of the course. Through the organization process, planning of ideas resulted in a new thought structured according to the standards of the academy, but that is not limited to this space and norms.

Having a contribution that goes beyond scientific writing, during this learning path was broadly, that is, creation of application, websites, books, articles, methodologies of pedagogical practices. All this experience will positively impact the future as a researcher and physical education professional. 
In this context, all production during the master's degree also contributes both quantitatively and qualitatively to the scientific production of the northern region, positively impacting it and the master's program. In addition to the importance in the contribution of scientific creation and dissemination, the productions tend to positively impact the evaluation and maintenance of the PROFEPT-IFAP program, carried out by CAPES.

\section{REFERENCES}

BALBINO, S. I.; URT, S. D. C. Prática Pedagógica em Educação Física para a Educação Integral em Tempo Integral. Pensar a Prática, v. 21, n. 4, p. 775-785, 2018.

CAPES. Ficha de Avaliação - Programas Acadêmicos e Profissionais Área 46: Ensino. Brasília DF, 2020. Disponível em: < https://www.gov.br/capes/pt-br/centraisde-conteudo/FICHA_ENSINO.pdf >. Acesso em: 14 Jun 2021.

COUTINHO, R. X. A influência da Produção Científica nas Práticas de Professores de Educação Física, Ciências e Matemática em Escolas Públicas Municiais de Uruguaiana - RS. 2010. 94p. (Mestrado). Universidade Federal de Santa Maria, Santa Maria RS.

FALASTER, C.; FERREIRA, M. P.; GOUVEA, D. M. R. D. O efeito da publicação científica do orientador na publicação dos seus orientados. Revista de Administração Contemporânea, v. 21, n. 4, p. 458-480, 2017.

GOOGLEANALYTICS. Google Analytics Aplaticativo Oficial EFE - Pagina Inicial. 2021. Disponível em: < https://analytics.google.com/analytics/web/?authuser=1\#/p265457828/reports/default home >. Acesso em: 14 Jun 2021.

MACHADO, M. F. R. C.; URBANETZ, S. T. Mestrado profissional em educação profissional e tecnológica no Instituto Federal do Paraná: desafios e expectativas. Atos de Pesquisa em Educação, v. 14, n. 2, p. 885-903, 2019. 
MAIA, R. T. A importância da disciplina de metodologia científica no desenvolvimento de produções acadêmicas de qualidade no nível superior. Revista Urutágua, v. 14, n. 1, 2008.

PEREIRA, T. Z. M.; SILVEIRA, C. A Produção Acadêmica Da Região Norte: Uma Análise Na Ata Do Xi Encontro Nacional De Pesquisa Em Educação Em Ciências. REAMEC - Rede Amazônica de Educação em Ciências e Matemática, v. 7, n. 2, p. 245-260, 2019.

PLAYCONSOLE. Google Play Console Painel - EFE EduFIsEPT. 2021. Disponível em:

https://play.google.com/console/u/0/developers/4760644030222400117/app/497210 7118591571772/app-dashboard?timespan=thirtyDays\&showKpiMenu=null >. Acesso em: 14 Jun 2021.

RMNC. Revista Multidisciplinar Nucleo do Conhecimento. São Paulo SP, 2021. Disponível em: < https://www.nucleodoconhecimento.com.br/ >. Acesso em: 14 Jun 2021.

ROSSI, A. V. Sobre A Valorização Das Contribuições Da Divulgação Científica No Brasil. In: VOIGT, C. L. (Ed.). O ensino de química. Ponta Grossa PR: Atena Editora, v.1, 2019. cap. 11, p.136-148.

RSD. Research, Society and Development. Vargem Grande paulista SP, 2021. Disponível em: < https://rsdjournal.org/index.php/rsd >. Acesso em: 14 Jun 2021.

SIDONE, O. J. G.; HADDAD, E. A.; MENA-CHALCO, J. P. A ciência nas regiões brasileiras: evolução da produção e das redes de colaboração científica. Transinformação, v. 28, n. 1, p. 15-32, 2016.

URBANETZ, S. T.; CASSIANO, E. L.; BETTONI, V. O Mestrado Profissional Em Educação Profissional E Tecnológica-Profept-E O Significado Dessa Oferta De 
Formação Em Pós Graduação No Brasil. Movimento-revista de educação, v. 7, n. 14, 2020.

VIANA, V. N.; DIAS, C. A. G. D. M. Educação Física e EPT - Temáticas em Educação Profissional e Tecnológica (EPT). Macapá AP: 2020. 45 p. ISBN 97865-86069-90-7. Disponível em:

https://www.nucleodoconhecimento.com.br/livros/wp-content/uploads/2020/09/livroeducacao-Fisica-e-EPT-educacao-profissional-e-tecnologica-2020.pdf >.

Physical Education and PTE - Topics in Professional and Technological Education (PTE). Macapá AP: 2020b. 45 p. ISBN 978-65-86069-89-1. Disponível em: < https://www.nucleodoconhecimento.com.br/livros/en/education/physicaleducation-and-pte $>$.

VIANA, V. N. et al. Quadras de esportes em condições de uso adequado no Brasil: influência no ensino-aprendizagem nas aulas de Educação Física (2015). Research, Society and Development, v. 9, n. 8, p. e239985704, 2020. Disponível em: < https://rsdjournal.org/index.php/rsd/article/view/5704/4727 >.

VIANA, V. N. et al. Manuel de pratiques en éducation physique en éducation professionnelle et technologique utilisant l'application gratuite EFE - EPTFIS. Revista Científica Multidisciplinar Núcleo do Conhecimento, v. 5, p. 4, 2021d. Disponível em: < https://www.nucleodoconhecimento.com.br/education-physics-fr/manuel-depratiques $>$.

. Manuale di pratiche in educazione fisica nell'educazione professionale e tecnologica utilizzando l'applicazione gratuita EFE - EPTFIS. Revista Científica Multidisciplinar Núcleo do Conhecimento, v. 5, n. 4, p. 65-76, 2021e. Disponível em: < https://www.nucleodoconhecimento.com.br/educazione-fisica-it/manuale-dipratiche $>$.

Handbuch der Praktiken im Sportunterricht im beruflichen und technologischen Unterricht mit der kostenlosen Anwendung EFE - EPTFIS. Revista Científica Multidisciplinar Núcleo do Conhecimento, v. 5, n. 4, p. 65- 
76, 2021f. Disponível em: < https://www.nucleodoconhecimento.com.br/bildungphysik-de/handbuch-der-praktiken $>$.

. Пособие по практике физического воспитания в профессиональном и технологическом образовании с использованием бесплатного приложения EFE EPTFIS. Revista Científica Multidisciplinar Núcleo do Conhecimento, v. 5, n. 4, p. 65-76, 2021g.

Disponível em:

https://www.nucleodoconhecimento.com.br/образование-фииика-ru/пособие-попрактике >.

VIANA, V. N. et al. Manual De Praticas Em Educação Física Na Educação Profissional E Tecnológica Utilizando O Aplicativo Gratuito EFE - EPTFIS. Revista Científica Multidisciplinar Núcleo do Conhecimento, v. 5, n. 4, p. 65-76, 2021. Disponível em: < https://www.nucleodoconhecimento.com.br/educacao-fisica/manual-depraticas $>$.

. Manual Of Practices In Physical Education In Professional And Technological Education Using The Free Application EFE - EPTFIS. Revista Científica Multidisciplinar Núcleo do Conhecimento, v. 5, n. 4, p. 65-76, 2021b. Disponível em: < https://www.nucleodoconhecimento.com.br/education-physics-en/manual-ofpractices $>$.

. Manual De Prácticas En Educación Física En Educación Profesional Y Tecnológica Utilizando La Aplicación Gratuita EFE - EPTFIS. Revista Científica Multidisciplinar Núcleo do Conhecimento, v. 5, n. 4, p. 65-76, 2021c. Disponível em: < https://www.nucleodoconhecimento.com.br/educacion-fisica-es/manual-depracticas $>$.

YAMAGUCHI, K. K. D. L.; FURTADO, M. A. S. A Escrita Científica Como Aprendizagem Contextualizada: Uma Abordagem Metodológica A Partir De Um Experimento De Mistura De Cores In: VOIGT, C. L. (Ed.). O ensino de química. Ponta Grossa PR: Atena Editora, v.1, 2019. cap. 12, p.149-158.

Submitted: June, 2021. 
Approved: June, 2021. 